\title{
Some factors affecting the digestion of glycaemic carbohydrates and the blood glucose response
}

\author{
M Charlyn Vosloo
}

\section{OPSOMMING}

Die voedselindustrie sal baat by groter begrip van die faktore verantwoordelik vir die metaboliese kenmerke van koolhidraatryke voedsel, daar dit oordeelkundige seleksie van bestanddeelopsies sal bevorder. Hierdie faktore sluit onder meer in die botaniese oorsprong van die koolhidraat, die hoofklasse en subklasse van die koolhidraat, die chemiese en fisiese struktuur van die koolhidraat, kalsium, gaarmaak, sure en byvoegings tot geformuleerde voedsel. Die afgelope dekade is groot vordering gemaak wat betref die verstaan van die faktore wat ' $n$ invloed uitoefen op die snelheid van vertering van koolhidraatvoedsels. Hierdie oorsig poog om die onderwerp holisties te benader. Op dié wyse behoort dit begrip in die hand te werk van hoe die bloedglukoserespons tot voedsel, vanweë verskillende faktore op molekulêre, maar ook op voedingstofsamestellingsvlak, en in voedselformules, beïnvloed kan word met die oog op aanpassings aan die glukemiese indeks en gepaardgaande toepassings. Daarbenewens kan hierdie faktore ook ' $\mathrm{n}$ rol speel in die metodologie wat toegepas word om glukemiese respons te bepaal. In die verlede is kritiese kommentaar gelewer op fisiologiese en op tegniese/statistiese vlak, maar kommentaar wat die navorser maan tot versigtigheid wat betref die impak van voedselreaksies op die metodologie is nie genoegsaam in die literatuur aangespreek nie. Derhalwe word ' $n$ paar kritiese punte in hierdie opsig ook geopper

\section{- Dr MC Vosloo}

Department of Consumer Science University of Stellenbosch

\section{INTRODUCTION}

One of the myths pertaining to the nutritional value of carbohydrate foods is the speed of digestion. Traditionally it was believed that quick, effective and complete digestion was linked to carbohydrate foods of a high quality. In the past four decades this understanding has fortunately faded, but nevertheless Jenkins et al (1994:99) stated relatively recently that "The major reason for the lack of general acceptance of the possible nutritional value of reducing the rate of absorption of starchy foods is the lack of understanding of mechanisms by which slow absorption confers physiological benefits".

There is increasing evidence that "low-glycaemicindex, or lente, diets" (Björck et al, 1994:699S) not only benefit people with diabetes and hyperlipidaemia, but are also beneficial for healthy subjects. Gaining an understanding of the factors responsible for the metabolic features of carbohydrate foods will benefit members of the food industry who aim at improving the properties of food by making inter alia more judicious choices of ingredient materials (Björck et al, 1994).

The blood glucose response to food is reflected by the glycaemic index of the particular food. Glycaemic in$\operatorname{dex}(\mathrm{Gl})$ has been accepted as "an index that indicates the relative extent to which post prandial blood sugar increases" (Nishimune et al, 1991:414) and is defined as the incremental area under the blood glucose response curve elicited over a two-hour period by a 50-g carbohydrate portion of a food, expressed as a percentage of the response to the same amount of carbohydrate from a standard food taken by the same subject (Anderson, 1997, Wolever, 1999). The South African Department of Health (2002:10) gives the same definition, though stipulating glucose as standard and not referring to the time period (e.g. two or three hours). In an unofficial copy of the draft (Department of Health, 2003:11) they refer to the particular carbohydrates affecting blood glucose response as "glycaemic (available) carbohydrate". This available carbohydrate - glycaemic carbohydrate - is available for metabolism and is the summation of the analytical values of mono, di- and oligosaccharides, starch and glycogen but excludes fructooligosaccharides and other non-digestible oligosaccharides and resistant starch (Department of Health, 2002:10).

This review aims at identifying as comprehensively as possible the food factors that may slow down the absorption of starch with concomitant benefit in lowering the blood glucose response. However, these factors 
should not be seen in separate compartments, they are interrelated and though examples are given to illustrate one aspect, it should be borne in mind that another/more factors are likely to be involved, thus becoming "moderator variable/s" for the one factor being discussed.

At the end of the review short cautionary notes will be made regarding the impact of production/preparation processes on the methodology of the determination of the glycaemic index.

\section{FACTORS INFLUENCING THE BLOOD GLUCOSE RESPONSE}

\section{The composition of food}

The composition of the food or the meal will influence blood glucose response. This fact could partially explain the low GI of milk products. For example, skim milk contains 4,9\% carbohydrate (Langenhoven et al, 1991:9) and has a Gl of 32 (Brand Miller et al, $1996: 223)$. It is therefore classified as a low-Gl food (Dept of Health, 2002:37). As opposed to this, freshly boiled potato contains $16,7 \%$ carbohydrate (Kruger et al, 1998:26), though literature reports different values: from 12,8\% (English \& Lewis, 1991 in Soh \& BrandMiller, 1999) to $17,8 \%$ (Holland et al, 1991 in Soh \& Brand-Miller, 1999). The $\mathrm{Gl}$ of potato thus varies, but is generally believed to be above 70 (Soh \& BrandMiller, 1999) and therefore classified as a high-GI food (Dept of Health, 2002:37). Note, however, that the protein content of milk versus potato differs, also the type of glycaemic carbohydrate, which in turn become moderator variables.

Factors outside the digestive tract can also cause breakdown of glycaemic carbohydrates. Enzymes (e.g. a-amylase) present in food (e.g. egg yolk) are not always inactivated during cooking (Vosloo \& Davel, 1991, McWilliams, 2001:368). Should such food, for example fried egg with soft yolk/insufficiently heated egg in crème anglaise and other creams (Gastronomique committee \& Robuchon, 2001:364) be taken in with other glycaemic carbohydrate foods such as toast or cake, and the degree of enzyme inactivation is not controlled, this factor becomes a variable in research. Acid hydrolysis will also cause breakdown during heating (Bennion \& Scheule, 2000:256, McWilliams, 2001:137) and affect the rate of digestion. The disaccharide, sucrose, is particularly susceptible to hydrolysis (McWilliams, 2001:137), while starch, after heating and gelatinisation, will be hydrolysed at a pH of 4 and lower (Bennion \& Scheule, 2000:256, McWilliams, 2001:137). In this way low molecular compounds will be formed (Charley \& Weaver, 1998:155) which will result in an increase in blood glucose response (Cummings et al, 1997).

Another fundamental that should be borne in mind is resistance to endogenous $\alpha$-amylase. Factors determining this resistance are tabulated in the discussion (Table 2) further on.
Apart from the above principles the following factors will be discussed:

\section{Botanical source of the glycaemic carbohydrate}

Foods within the same botanical classification can have very different glycaemic indexes. For example, potatoes and sweet potatoes are both tubers, but potato has a high $\mathrm{GI}$ value $(\mathrm{GI}>70)$ (Soh \& Brand-Miller, 1999), while sweet potato has a low $\mathrm{GI}$ value $(\mathrm{Gl}<55)$ (Brand-Miller \& Foster-Powell, 2000:23). Thickly flaked rolled oats has a $\mathrm{Gl}$ of $70-78$ versus thickly flaked rolled barley with a GI of 94 (white bread as standard) (Granfeldt et al, 2000). The authors ascribe the difference to differences in the botanical nature of the cereals. Cummings and Englyst (1995) explain this inter alia in terms of the differences in size and crystallinity of the starch granules in food. X-ray diffraction patterns ( $A, B$ and $C$ ) differ for the starch types. Type A pattern is associated with cereals, B with banana, potato and other tubers, while $C$ is associated with legumes. According to these authors starch granules consisting mainly of starch with the $B$ and $C$ type $X$-ray diffraction patterns, will be more resistant to the action of pancreatic amylase thus retarding starch digestion as reflected by a flattened blood glucose response curve.

\section{The class of carbohydrate present in food}

The main classes of carbohydrates, subclasses and the physiology with regard to the operative part of the digestive tract and speed of digestion (or whether fermented instead) is summarised in Table 1 (adapted from Cummings et al, 1997 with additional supporting references).

The monosaccharides present in foods as free sugars, or as components of sucrose, are metabolised differently (Asp, 1995), although both are digested and absorbed in the duodenum (Cummings \& Englyst, 1995). Fructose has a much lower blood glucose response $(\mathrm{Gl}=23)$ (Brand Miller et al, 1996:238) than glucose $(G I=100)$ (Brand Miller et al, 1996:235). Where the disaccharides are concerned, sucrose has a $\mathrm{Gl}$ of 69 , while that of lactose equals 46 (Brand Miller et al, 1996:235).

The most common oligosaccharides are a-galactosides (raffinose, stachyose and verbascose) and fructooligosaccharides (Asp, 1995). The latter are also referred to as prebiotics (Kolida et al, 2000, Cummings et al, 1997) as they are not readily digested and metabolised, but stimulate the growth of health-promoting bifidobacteria in the colon and become fermented by the intestinal microflora. During this process of fermentation they suppress the growth of pathogenic bacteria (Cummings et al, 1997) such as Clostridium perfringens, Clostridium difficile, proteolytic Bacteroides species and pathogenic species of Enterobacteriacea (Kolida et al, 2000). For this reason oligosaccharides have other health benefits than the primary function of provision of energy generally associated with carbohydrates. This phenomenon that oligosaccharides cannot provide substantial amounts of en- 
TABLE 1: $\quad$ THE MAIN CLASSES, SUBCLASSES AND PHYSIOLOGY WITH REGARD TO THE OPERATIVE PART OF THE DIGESTIVE TRACT AND SPEED OF DIGESTION

\begin{tabular}{|c|c|c|}
\hline Main classes & $\begin{array}{c}\text { Subclasses (type of sacharide and } \\
\text { alpha- and beta-linkages) }\end{array}$ & Physiology \\
\hline Sugars & $\begin{array}{l}\text { Monosaccharides: glucose and fructose } \\
\text { Disaccharide: sucrose, maltose trehalose, } \\
\text { lactose } \\
\text { Sugar alcohols: sorbitol, maltitol and lactitol }\end{array}$ & $\begin{array}{l}\text { Absorbed in the ileum; glucose gives a more } \\
\text { rapid response than fructose (Anderson, } \\
1997: 1491 \text { ) } \\
\text { Absorbed in the duodenum. Sucrose gives a } \\
\text { more rapid response than fructose } \\
\text { Poorly absorbed and partially fermented }\end{array}$ \\
\hline $\begin{array}{l}\text { Oligo- } \\
\text { saccharides }\end{array}$ & $\begin{array}{l}\text { Malto-oligosaccharides ( } \alpha \text {-glucan) } \\
\text { Other oligosaccharides: Fructo-oligo- } \\
\text { saccharide and galacto-oligosaccharide } \\
\text { (Non-digestible oligosaccharide, NDO) }\end{array}$ & $\begin{array}{l}\text { Physiological behaviour can differ } \\
\text { Not hydrolised by human digestive enzymes. } \\
\text { Fermented in the colon }\end{array}$ \\
\hline $\begin{array}{l}\text { Poly- } \\
\text { saccharides }\end{array}$ & $\begin{array}{l}\text { Starch (a-glucan): amylose and amylopectin } \\
\text { Non-starch polysaccharides: cellulose, } \\
\text { hemi-cellulose, pectin, hydrocolloids }\end{array}$ & $\begin{array}{l}\text { Raw starch is not digested (Cummings \& } \\
\text { Englyst, 1995) } \\
\text { When gelatinised (being cooked in moist heat) } \\
\text { it is digested easily and the speed of digestion } \\
\text { is determined by many factors (Beyer, } \\
2004: 9 \text { ). Cooked starch may become resistant } \\
\text { to the action of enzymes of the digestive tract, } \\
\text { e.g. when starch is retrograded (Asp \& Björck, } \\
1992 \text { ) } \\
\text { Not hydrolysed by human digestive enzymes. } \\
\text { Fermented in the colon }\end{array}$ \\
\hline
\end{tabular}

TABLE 2: $\quad$ FACTORS CONTRIBUTING TO RESISTANCE OF STARCHES

\section{Nature of the granule and the starch}

- Resistant granules (raw potato and underripe banana - underripe banana with GI 30; overripe banana with GI 52 (Brand Miller et al, 1996:224)

- Raw starch (especially starch with the B-, but also the C-type X-ray diffraction pattern)

- Starch which is encapsulated in the plant cell or the plant tissue

- Retrograded amylase (Asp \& Björck, 1992) and amylopectin (Toufeili et al, 1999)

- Modified starch

Processes

- Canning of starchy foods such as potatoes (Soh \& Brand Miller, 1999:253) may cause retrogradation due to cooling after gelatinisation

- Staling of bread due to retrogradation

- Competition for moisture: fibre retains moisture when cooking or baking cereal products (McWilliams, 2001:193) and limits the available water required for gelatinisation; sucrose retains water when cooking or baking cereal products and limits the available water required for gelatinisation (Bennion \& Scheule, 2000:256). The same effect is suggested by Toufeili et al (1999) in an investigation on the impact of crosslinked barley starch

Complex formation during modifications or formulations

- Amylose lipid complexes (Asp \& Björck, 1992)

- Starch protein complexes (Vosloo \& Davel, 1991)

ergy is ascribed to the inability of the human digestive enzymes to breakdown the a-galactosidic linkages (Asp, 1995), although gastric acid is able to partially breakdown fructooligosaccharides (Cummings \& Englyst, 1995).

Polysaccharides (see Table 1) include starch and nonstarch polysaccharides. Cooked starch that has become gelatinised and whereafter the cell walls have ruptured (Drapon \& Godon, 1987:285, Asp, 1995) is digested easily. The process starts with the amylase in the mouth; thereafter the process of digestion is continued through the action of the pancreatic enzyme, $\alpha$-amylase (Beyer, 2004:15-16). Only a small amount is hydrolysed in the stomach (Levin, 1994). The non-starch polysaccharides, as well as the resistant starches (see later) pass relatively unchanged to the colon where they are partially fermented (Cummings \& Englyst 1995, Cummings et al, 1997).

Chemical and physical structure of the starch molecule or granule 
TABLE 3:

FIBROUS COATING AROUND LEGUMES AND SEEDS LOWERS THE GI (WHITE BREAD USED AS REFERENCE ) OF FOODS

\begin{tabular}{|l|l|l|c|}
\hline \multicolumn{1}{|c|}{ Food } & GI & \multicolumn{1}{c|}{ Food } & GI \\
\hline Whole grain barley bread & 58 & Whole meal barley bread & 100 \\
\hline Whole grain barley porridge & 35 & Whole meal barley porridge & 98 \\
\hline Whole red lentils & 36 & Ground red lentils & 70 \\
\hline Whole white beans & 40 & Ground white beans & 74 \\
\hline Whole red kidney beans & 36 & Ground red kidney beans & 70 \\
\hline Whole brown beans & 40 & Ground brown beans & 74 \\
\hline
\end{tabular}

Various chemical and physical phenomena contribute to differences in carbohydrate digestion and therefore blood glucose response.

\section{Crystallinity Raw starch is crystalline. When} cooked it becomes amorphous and readily digested. However, on cooling it retrogrades (recrystallises) and becomes amylase-resistant.

\section{Amylose and amylopectin molecules Research} has shown that the ratio of amylose to amylopectin molecules in food has an effect on the glycaemic response of food (Brand Miller et al, 1996:32, Nishimune et al, 1991). Amylose consists of long, straight chains of glucose units densely arranged, while amylopectin contains branched chains of glucose units that are larger and more open (McWilliams, 2001:509, Bennion \& Schuele, 2000:248, Charley \& Weaver, 1998:141,142), have a lower density and are digested more quickly (Brand Miller et al, 1996:33). There are exceptions to this generalisation. Jarvi et al (1999) report a GI of 50 for ordinary maize products containing $25 \%$ amylose, and a $\mathrm{Gl}$ of 81 for high-amylose maize flour, containing $70 \%$ amylose; these authors also report a GI of 68 for ordinary maize starch muffins and a GI of 96 for high-amylose maize starch muffins using white bread as reference and based on predictions of in vitro assays by Granfeldt (1992 in Jarvi et al, 1999).

Structural integrity of cell wall and starch granules Preserving the structural integrity of the cell and that of the starch granule is a determining factor for slow glycaemic response: "structural properties that limit the availability of starch for enzymic degradation ... (are important)" (Asp, 1995:932S). Starch breakdown also occurs as a result of the action of acids (McWilliams, 1995:247). Research articles are available where this implication (impact of starch integrity on blood glucose response) becomes clear, e.g. that of Kidmose and Martens (1999).

Resistant starch There are many reasons why starch becomes resistant to breakdown by enzymes of the human digestive tract resulting in these products passing through the small intestine without being digested (Cummings \& Englyst, 1995). A summary is presented (see Table 2) of circumstances that give rise to resistance. The original summary by Asp and Björck (1992) has been adapted and supplemented with additional references, especially from Cummings and Englyst (1995).
Particle size and processing of the starch granule The fibrous coating around legumes and seeds serves as a physical barrier, delaying the action of enzymes on starch. Legumes, and all cereals and seeds used in bread or cereals used in porridge, serve as examples (Asp \& Björck, 1992) (see Table 3, adapted from Jarvi et al, 1999). Brand Miller et al (1996:30) report rice varieties to be an exception.

Milling, beating, shearing and refining of foods also affect cell and granule integrity. These processes also decrease particle size and promote absorption of water and breakdown by enzymes. The glycaemic index value of such food increases (Foster-Powell \& Miller, 1995).

This also applies to other foods. Apple puree has a higher GI (Gericke \& Muller, 1987) than whole raw apple. This phenomenon has been sufficiently explained by Asp (1995) (see discussion on cell integrity).

Fibre type and fibre content According to Nishimune et al (1991) and Trout et al (1993) an increase in the total fibre content of food can delay the glycaemic response. Nishimune et al (1991) explain this hypoglycaemic effect in terms of five mechanisms. Firstly, fibre delays the digestion of starch in the stomach; secondly, fibre will delay the transition time of the stomach contents to the duodenum; thirdly, fibre will delay the diffusion tempo of different saccharides in the duodenum, and fourthly, fibre will delay the hydrolysis of polysaccharides in the upper part of the duodenum. Finally, fibre will delay the absorption tempo of monosaccharides through the microvilli of the epithelial cells of the jejunum and the upper part of the ileum (Nishimune et al, 1991).

Wolever and Miller (1995) point out that the effect of fibre on $\mathrm{Gl}$ depends on whether purified fibre is added or whether it is fibre naturally occurring in foods. When purified fibre is added, "there is fairly consistent evidence that viscous (soluble) types of fibre reduce blood glucose ... Purified nonviscous (insoluble) fibers have little or no effect on postprandial blood glucose (Wolever \& Miller, 1995:225S). Foods with soluble fibre are oats, oats fibre, barley, legumes, pasta, maize and certain fruits and vegetables, and they have a lowering effect on the glycaemic index. Sources of insoluble fibre include digestive bran, wheat, brown rice, and do not impact on the digestibility of carbohydrate foods in which they are present 
(Gericke \& Muller, 1987). This differentiation between soluble and insoluble fibre is questioned by the joint $\mathrm{FAO} / \mathrm{WHO}$ expert consultation on carbohydrates in human nutrition, due to the lack of clear distinction in the analytical methodology and physiological effects (FAO/WHO, 1997:75, Medical Research Council, 2001, Nantel, sa.).

Whether or not there is a difference between the effects of the two types of fibre, fibre intake per se is associated with an increase in insulin sensitivity, resulting in lower plasma levels of insulin (Giacco et al, 2002) and lowered blood glucose levels (Gericke \& Muller, 1987).

Phytochemicals Phytic acid, lectins and polyphenols (tannins) are plant chemicals (phytochemicals), regarded as amylase inhibitors and are found especially in legumes (Thompson, 1988). They slow down the digestion of carbohydrate in the digestive tract resulting in flattened blood glucose response curves (Thompson, 1988). Thus the glycaemic index of the food is lowered (Thompson, 1988; Leeds et al, 1998:36). Thompson (1988:124) reports, “... the legumes that contain the highest concentrations of phytic acid, lectins and tannins were digested the slowest and produced the flattest blood glucose response". Cereals, vegetables and legumes are examples of food that contain phytochemicals (Thompson, 1988).

\section{Calcium}

Calcium is required for the stabilisation of exogenous amylase against denaturation caused by heat or alkali (as would be applicable in food systems) (Reed, 1966:49). Foods containing calcium (e.g. egg-starch pastes being cooked at temperatures where amylase is active $\left(40-80{ }^{\circ} \mathrm{C}\right)$ (Vosloo \& Davel, 1991) will therefore be more readily hydrolysed during heating, as calcium aids the breakdown in lower units of polymerisation due to its stabilisation of exogenous amylase thus increasing the blood glucose response to the food. Calcium is also required for the action of amylase (Thompson, 1988) in the body. This means that should a food contain an ingredient high in calcium it is possible that the mechanism for hydrolyses in vivo will be more successful. However, should the food ingredient also contain protein, this will become an extraneous variable unless the protein content is controlled, as protein interacts with starch (Vosloo \& Davel, 1991) and thus slows down the blood glucose response.

\section{Cooking}

The starch in raw food is stored in hard compact granules and therefore difficult to digest (Brand Miller et al, 1996:31). During the cooking of starch the heat and water cause the hard compact granules to swell (Charley \& Weaver, 1998:149) and individual molecules are released. The starch is fully gelatinised pasted - when most of the starch molecules escape into the aqueous solution, with gelatinisation and pasting regarded as sequential processes (Bennion \& Scheule, 2000:254). This process of pasting eventu- ally leads to the total disruption of the granules. These free starch molecules are more easily digested because of particle disintegration (Asp, 1995), giving the a-amylase easier access (Drapon \& Godon, 1987:285, Asp, 1995) and a larger surface for action. This leads to an increase in glycaemic index (Brand Miller et al, 1996:31). Should the cooking process have been incomplete the starch would have been more resistant (Asp \& Björck, 1992) resulting in slow digestion and absorption and a lower glycaemic index.

During the cooking of starch pastes, e.g. starchy sauces and puddings, gelatinisation is determined by free moisture (Bennion \& Scheule, 2000:256). Products with a relatively "high concentration of sucrose are more effective in delaying swelling ... than are equal concentrations of monosaccharides ... At a concentration of $20 \%$ or more all sugars and syrups cause a decided decrease in the gel strength of starch pastes ..." (Bennion \& Scheule, 2000:256). The delay in the gelatinisation is ascribed to the sugar competing with the starch for moisture (Bennion \& Scheule, 2000:256). In the same way fibre will influence moisture retention, for instance wheat fibre/bran (McWilliams, 2001:193). The same applies for different levels of crossbonded waxy barley starch as can be concluded from the research by Toufeili et al (1999). "The process of staling decreased with increasing levels of cross-linking [of the crossbonded amylopectin barley starch] possibly owing to restrictions in starch swelling" (Toufeili et al, 1999: 1860). Findings of Toufeili et al (1999) set the scene for other research questions pertaining to the glycaemic value, e.g. What is the impact of different levels of crossbonded starch on the glycaemic index value of a cereal product? On the one hand it will, according to the theory proposed by Toufeili et al (1999), possibly delay gelatinisation, thereby lowering the glycaemic response. On the other hand, it will delay retrogradation, thereby delaying formation of resistant starch and increasing blood glucose response. Obviously, it will be a complex research question.

Cooking not only influences the rate of starch digestion through its effect on starch, but also through its effect on amylase inhibitors which are very heat labile (Thompson, 1988, Alonso et al, 1998) and therefore amylase inhibitors are "not detected in many ready-toeat cooked foods" (Thompson, 1988:126).

\section{Acids}

Organic acids found in foods, e.g. malic, citric and tartaric acids, lower the glycaemic index of food (Guevarra \& Panlasigui, 2000). However, when the ratio and amounts of acid become significant they contribute to acid hydrolysis (Bennion \& Scheule, 2000:256, McWilliams, 2001:137).

It should be borne in mind that the traditional view was that only human amylase contributes to starch breakdown. The present understanding acknowledges that hydrochloric acid in the stomach also breaks down the a-galactosidic linkages of the oligo- 


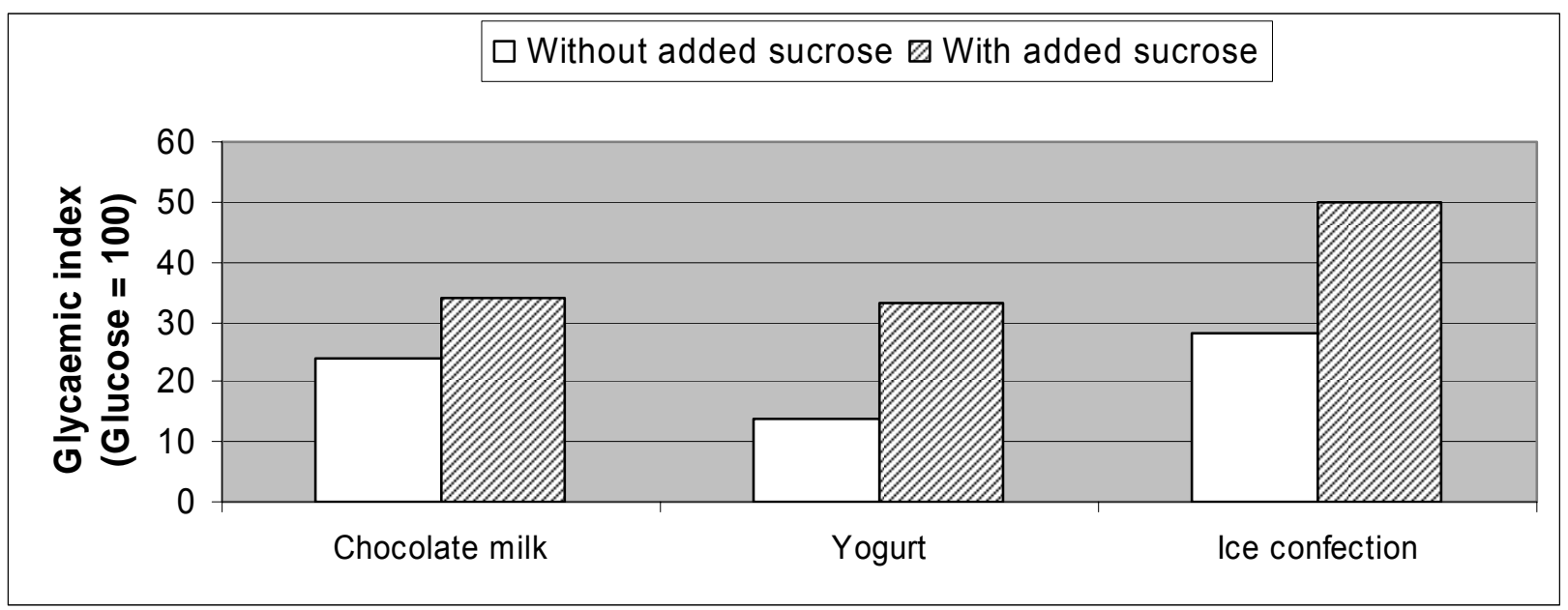

FIGURE 1:

THE EFFECT OF ADDED SUCROSE ON THE GLYCAEMIC RESPONSE OF MILK

saccharides (Cummings \& Englyst, 1995). Taking into account that the acid of the stomach is strong $-\mathrm{a} \mathrm{pH}$ of between 1 and 4 (Beyer, 2004:9) and that starch is hydrolysed in vitro by acids at a $\mathrm{pH}$ of $<4$ (Bennion \& Scheule, 2000:256, McWilliams, 2001:172) then the question arises why more starch digestion is not evident in the stomach. Possibly this is due to insufficient heat energy, as heat is required for acid hydrolysis (Charley \& Weaver, 1998:155, Bennion \& Scheule, 2000:256). Therefore literature does not report significant hydrolysis by hydrochloric acid. Instead, it is consistently reported that most of the digestion of carbohydrates occurs in the intestine (Asp, 1995, Levin, 1994, Matthews \& Van Holde, 1991:459).

\section{Additions to a food formulation}

For the purposes of food product development, additions to a food formulation should be considered on their own when the impact of the formula on blood glucose response is a consideration. Additions refer to the food ingredients combined in a basic formula during product development. The process of food product development requires an awareness of all the factors mentioned above in order to plan product formulations with a view to particular glycaemic index claims, otherwise the food interactions will produce unanticipated results within such a complex food system as is applicable in food product development.

There are many mechanisms that will explain the impact of additions on glycaemic index. Six are discussed below.

The glycaemic index of the ingredient to be added to the formula For instance, soya flour has a GI of 30 and can decrease the glycaemic index of a batter/ dough. Sucrose with a GI of 65 will have the opposite effect when added to yoghurt with a glycaemic index of 33 , as illustrated by research done by Brand-Miller and other authors with the data reported by Wolever and Miller (1995) (see Figure 1). The added sucrose also alters the protein: glycaemic carbohydrate ratio (less protein to glycaemic carbohydrate), hereby also contributing to an increase in the glycaemic index.

The impact of additions on hydration of starch and gelatinisation thereof Sugar, fat and proteins delay starch gelatinisation (Bennion \& Scheule, 2000:256). The effect of sugar is due to its hygroscopic nature, limiting available water for starch gelatinisation. This results in a decrease of the glycaemic index of the product, while fat and protein prevent hydration, thereby also decreasing the glycaemic index of the product. The fact that sugar decreases the glycaemic index of the product was illustrated by research done by Brand-Miller and other authors with the data reported by Wolever and Miller, (1995) (see Figure 2).

Similarly, fibre can also delay starch gelatinisation through moisture retention, causing less hydration and less moisture to be available for starch gelatinisation (McWilliams, 2001:193), thereby lowering the glycaemic response of a formulated food. Theoretically this has been proposed for crossbonded waxy barley starch (Toufeili et al, 1999) as well.

The impact of additions on retrogradation of starch Should a food component added to a formulation have an effect on retrogradation, a process causing food to become more a-amylase resistant (Asp \& Björck, 1992), the formulated food will impact on the glycaemic response. Toufeili et al (1999) did research on crossbonded amylopectin barley starch and found that crossbonded waxy barley starch delayed staling (retrogradation).

The impact of the added ingredient on the hydrolyses of the starch-containing components Should hydrolysis occur, lower polymer glucose-containing units with $\alpha-1-4$-glycosidic linkages are formed as intermediate breakdown products from the starch hydrolysis (Charley \& Weaver, 1998:155, Vosloo \& Davel, 1991). This breakdown occurs when aamylase is not sufficiently inactivated $\left(<80^{\circ} \mathrm{C}\right)$ during 


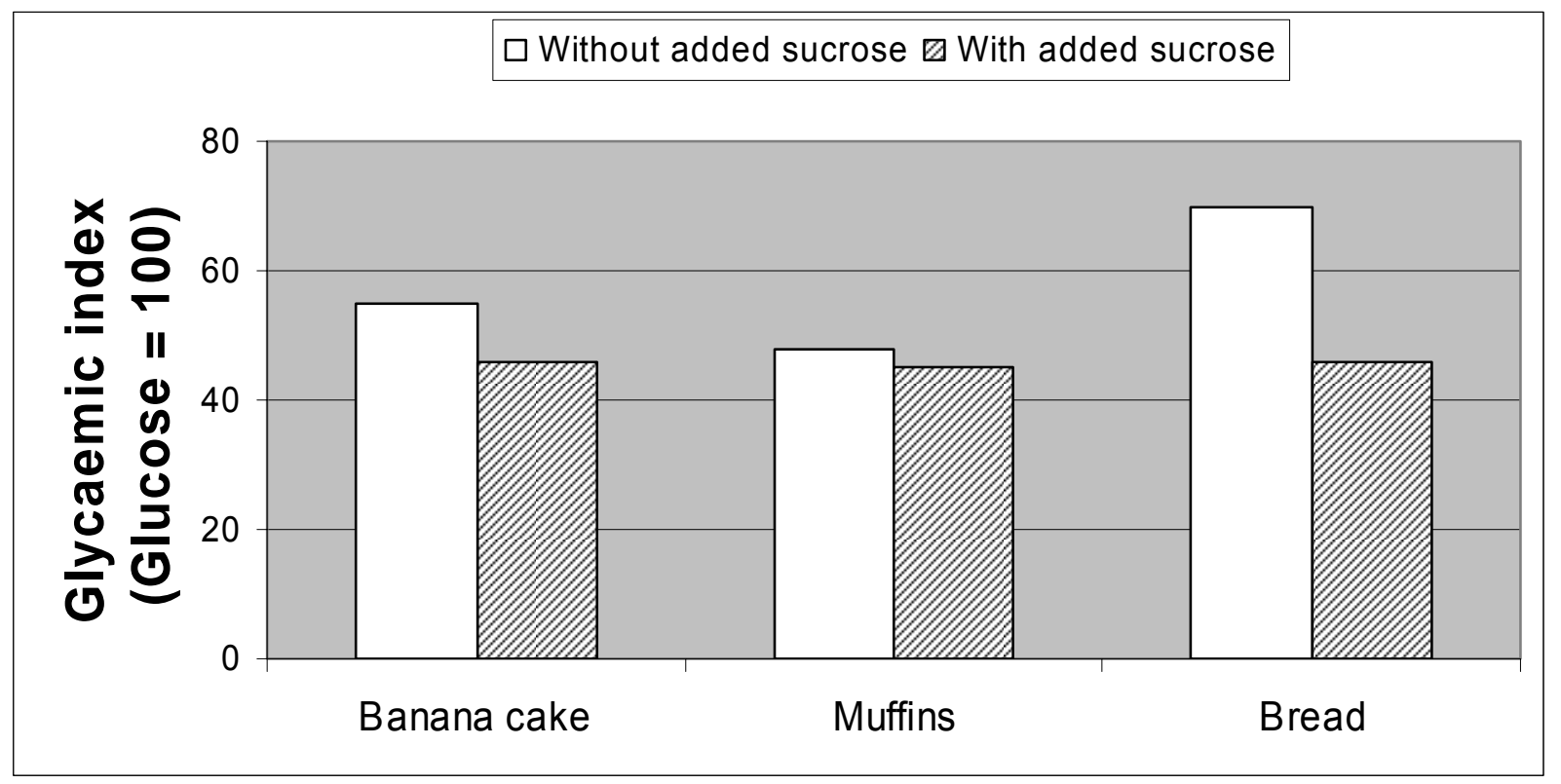

\section{FIGURE 2: THE EFFECT OF ADDED SUCROSE ON THE GLYCAEMIC RESPONSE OF BAKED CEREAL PRODUCTS (Wolever \& Miller, 1995:216S)}

the addition of raw egg to thickened starch pastes (McWilliams, 2001:368, Vosloo \& Davel, 1991) as is applicable when cream pies (McWilliams, 2001:368), egg-custard fillings (e.g. for Blitz Torte) and tarts, e.g. milk tart, are prepared (Vosloo \& Davel, 1991). Although the research reported by McWilliams (2001:368) and Vosloo and Davel (1991) was more concerned with the effect of the a-amylase on the viscosity of starch mixtures, this feature of starch degradation also has implications for the glycaemic index of these glycaemic carbohydrate foods and needs to be controlled during GI research. Another food example that may illustrate impact of the action of $\alpha$ amylase in meals is fried egg on toast when the setting temperature of the egg yolk is not controlled and this food is used in studies concerned with the blood glucose response of patients. Acids also cause breakdown during the heating of starch mixtures, e.g. starch filling for lemon meringue pie. Should the starch paste not be cooled and the temperature controlled in the cooling phase before adding the acid (in this case lemon juice) this becomes a variable in blood glucose response of patients to foods where this, or similar products - with substantial amounts of acid added to the product during or after heating become part of the menu plan.

The impact of the added ingredient on gastric emptying Ingredients which are a source of soluble fibre (Brand Miller et al, 1996:36) or contain crosslinked amylopectin barley starch (Toufeili et al, 1999) or fibre may delay gastric emptying and thereby lower the glycaemic index of foods.

Nutrient-interactions Complex-formation of protein (Vosloo \& Davel, 1991), lipids (Asp \& Björck, 1992), as well as calcium (Thompson, 1988) with the carbohydrates present in the ingredients of the food formula will impact on the blood glucose response of foods. Protein and fats lower the blood glucose response due to the interaction of protein and lipids with carbohydrates, which slows down the release of the available carbohydrate units. Calcium, on the other hand, increases the blood glucose response, as explained above.

\section{CONCLUSIONS}

This overview has made it clear that the glycaemic response to food is a complex phenomenon determined by many factors including the following: the botanical source of the carbohydrate, the main classes and subclasses of the carbohydrate, the chemical and physical structure of the carbohydrate, calcium, cooking, acids and additions to formulated foods. To be able to consider one factor successfully in reliable and valid research the researcher should be fully aware of extraneous variables (Bless \& HigsonSmith, 2000:154). Procedures should be accurately described and assumptions carefully investigated.

Fields that can benefit from this review include the researcher in the field of blood glucose response testing and the $\mathrm{Gl}$ of foods; the internist physician concerned with the diabetic patient; the dietician concerned with the diabetic patient or other dietary applications of the $\mathrm{Gl}$ of foods; and the food scientist/ technologist involved in food formulation aimed at making glycaemic index claims.

\section{REFERENCES}

ALONSO, R, ORÚE, E \& MARZO, F. 1998. Effects of extrusion and conventional processing methods on 
protein and antinutritional factor contents in pea seeds. Food Chemistry 63(4): 505-512.

ANDERSON, GH. 1997. Sugars and health. Nutrition Research 17(9):1485-1498.

ASP, N-G \& BJÖRCK, I. 1992. Resistant starch. Trends in Food Science and Technology 3(3):111114.

ASP, N-GL. 1995. Classification and methodology of food carbohydrates as related to nutritional effects. American Journal of Clinical Nutrition 61(Suppl):930S937S.

BENNION, M \& SCHEULE, B. 2000. Introductory foods. 11th Edition. New York. Prentice-Hall.

BEYER, PL. 2004. Digestion, absorption, transport and excretion of nutrients. In Mahan, LK \& EscottStump, S. (Eds). Food, nutrition, \& diet therapy. 11th Edition. Philadelphia. WB Saunders.

BLESS, C \& HIGSON-SMITH, C. 2000. Fundamentals of social research. An African perspective. 3rd Edition. Cape Town. Juta.

BJÖRCK, I, GRANFELDT, Y, LILJEBERG, $\mathrm{H}$, TOVAR, J \& ASP, N-G. 1994. Food properties affecting the digestion and absorption of carbohydrates. American Journal of Clinical Nutrition 59(suppl):699S$705 S$.

BRAND MILLER, J, FOSTER-POWELL, $\mathrm{K}$ \& COLAGIURI, S. 1996. The GI factor: The glycaemic index solution. Rydelmere. Hodder \& Stoughton.

BRAND-MILLER, J \& FOSTER-POWELL, K. 2000. The glucose revolution: G.I. plus. Sydney. Hodder Headline.

CHARLEY, H \& WEAVER, C. 1998. Foods: A scientific approach. 3rd Edition. New York. Prentice-Hall.

CUMMINGS, JH \& ENGLYST, HN. 1995. Gastrointestinal effects of food carbohydrate. American Journal of Clinical Nutrition 61(4)(suppl): 938S-945S

CUMMINGS, JH, ROBERFROID, MB, ANDERSON, H, BARTH, C, FERRO-LUZI, A, GHOOS,Y, GIBNEY, M, HERMONSEN, K, JAMES, WPT, KORVER, O, LAIRON, D, PASCAL, G \& VORAGEN, AGS. 1997. A new look at dietary carbohydrate: chemistry, physiology and health. European Journal of Clinical Nutrition 51:417-423.

DEPARTMENT OF HEALTH. 2002. Regulations relating to labelling and advertising of foodstuffs No $R$ 1055. Government Gazette 8 August 2002. Legislation to be promulgated under the Foodstuffs, Cosmetics and Disinfectants Act, Act No 54 of 1972. Pretoria. Department of Health.

DEPARTMENT OF HEALTH. 2003. Unofficial document relating to the labelling and advertising of foodstuffs. Legislation to be promulgated under the Foodstuffs, Cosmetics and Disinfectants Act, Act No 54 of 1972. Pretoria. Department of Health.

DRAPON, R \& GODON, B. 1987. Role of enzymes in baking. In Kruger, JE, Lineback, D \& Stauffer, CE. (Eds) 1987. Enzymes and their role in cereal technology. Minnesota. AACC.

FOOD AND AGRICULTURE ORGANISATION/ WORLD HEALTH ORGANISATION. 1997. Carbohydrates in human nutrition. Report 66. Annex 2: Dietary fibre and resistant starch analysis. Food and Agriculture Organisation (FAO). Rome.

FOSTER-POWELL, K \& MILLER, JB. 1995. International tables of glycemic index. American Journal of
Clinical Nutrition 62(Suppl):871S-893S.

GASTRONOMIQUE COMMITTEE \& ROBUCHON, J. 2001. Larousse Gastronomique. London. Hamlyn. GERICKE, GJ \& MULLER, Y. 1987. Glukemiese indeks van voedsel: 'n oorsig. Journal of Dietetics and Home Economics 15(3):89-92.

GIACCO, R, CLEMENTE, G \& RICCARDO, G. 2002. Dietary fibre in treatment of diabetes: myth or reality. Digestive and Liver Disease 34(Suppl2):S140-S144.

GRANFELDT, Y, ELIASSON, AC \& BJÖRCK, I. 2000. An examination of the possibility of lowering the glycaemic index of oat and barley flakes by minimal processing. Journal of Nutrition 130(9):2207-2214.

GUEVARRA, MTB \& PANLASIGUI, LN. 2000. Blood glucose response of diabetes mellitus type 11 patients to some local fruits. Asia Pacific Journal of Clinical Nutrition 9(4):303-308.

JARVI, AE, KARLSTRÖM, BE, GRANFELDT, YE, BJÖRCK, IE, ASP, N-GL, VESSBY, VOH. 1999. Improved glycemic control and lipid profile and normalized fibrinolytic activity on a low-glycemic index diet in type 2 diabetic patients. Diabetes Care 22(1):10-18.

JENKINS, DJA, JENKINS, AL, WOLEVER, TMS, VUKSAN, V, VENKET RAO, A, THOMPSON, LU \& JOSSE, RGJ. 1994. Low glycemic index: lente carbohydrates and physiological effects of altered food frequency. American Journal of Clinical Nutrition 59 (Suppl):706S-709S.

KIDMOSE, U \& MARTENS, HJ. 1999. Changes in texture, microstructure and nutritional quality of carrot slices during blanching and freezing. Journal of the Science of Food and Agriculture 79:1747-1753.

KOLIDA, S, TUOHY, K \& GIBSON, GR. 2000. The human gut flora in nutrition and approaches for its dietary modulation. BNF Nutrition Bulletin 25(3):223231.

KRUGER, M, SAYED, N, LANGENHOVEN, M \& HOLING, F. 1998. Composition of South African foods: vegetables and fruit. Supplement to the MRC food composition tables 1991. South African Food Composition Data. Parow. South African Medical Research Council.

LEEDS, A, BRAND-MILLER, J, FOSTER-POWELL, K \& COLAGUIRI, S. 1998. The GI Factor. London. Hodder \& Stoughton.

LEVIN, RJ. 1994. Digestion and absorption of carbohydrates - from molecules and membranes to humans. American Journal of Clinical Nutrition 55 (suppl):690S-698S.

MATHEWS, CK \& VAN HOLDE, KE. 1990. Biochemistry. Redwood City, California. Benjamin/Cummings.

McWILLIAMS, M. 2001. Foods. Experimental perspectives. 4th Edition. Upper Saddle River, New Jersey. Prentice-Hall.

MEDICAL RESEARCH COUNCIL. 2001. Foodfinder $^{\mathrm{TM}} 2$. User's Manual: Appendix 1: Nutrients. Tygerberg. Nutrition Intervention Research Unit, South African Medical Research Council.

NANTEL, G (sa.). Carbohydrates in human nutrition. [WWW document] http://www.fao.org/docrep/ X2650t02.htm

NISHIMUNE, T, YAKUSHIJI, T, SUMIMOTO, T, TAGUCHI, S, KONISHI, Y, NAKAHARA, S, ICHIKAWA, T \& KUNITA, N. 1991. Glycemic response and fiber content of some foods. American Journal of Clinical 
Nutrition 54(2):414-419.

REED, G. 1966. Enzymes in food processing. New York. Academic Press.

SOH, NL \& BRAND-MILLER, J. 1999. The glycaemic index of potatoes: the effect of variety, cooking method and maturity. European Journal of Clinical Nutrition 53:249-254.

THOMPSON, LU. 1988. Antinutrients and blood glucose. Food Technology 42(4):123-132.

TOUFEILI, I, HABBAL, $Y$, SHADAREVIAN, $S$ \& OLABI, A. 1999. Substitution of wheat starch with non-wheat starches and cross-linked waxy barley starch affects sensory properties and staling of Arabic bread. Journal of the Science of Food and Agriculture 79(13):1855-1860.
TROUT, DL, BEHALL, KM \& OSILESI, O. 1993. Prediction of glycaemic index for starchy foods. American Journal of Clinical Nutrition 58(6):873-878.

VOSLOO, MC \& DAVEL, El. 1991. Die invloed van eindtemperatuur op die $\alpha$-amilase aktiwiteit, vloeibaarheid en fermheid van eierstyselkooksels. [The effect of final temperature on the a-amylase activity, consistency and firmness of egg-starch pastes.] Journal of Dietetics and Home Economics 19(3):82-86.

WOLEVER, TMS \& MILLER, JB. 1995. Sugars and blood glucose control. American Journal of Clinical Nutrition 62(Suppl):212S-227S.

WOLEVER, TMS. 1999. Dietary recommendations for diabetes: high carbohydrate or high monounsaturated fat? Nutrition Today 34(2):73-77. 